\title{
De teimosias e resistências
}

\author{
Leituras de resistência: corpo, \\ violência, poder.
}

TORNQUIST, Carmen Susana et al.

Florianópolis: Editora Mulheres, 2009. v. 2.

Ao reivindicarmos o auxílio do convencional dicionário para atingir uma definição do termo "resistência", ele nos apresentará diversas possibilidades, mas algumas são especialmente significativas para o campo dos estudos de gênero e dos estudos feministas. A primeira refere-se à habilidade de um corpo reagir sobre a ação de outro corpo; a segunda faz menção à capacidade de suportar a fadiga, a fome, o esforço; a terceira aponta aquilo que resiste à vontade de outrem; e, por último, o agente de resistência seria um causador de embaraço.'

No encalço da representatividade histórica e discursiva da expressão "resistência" no campo dos estudos de gênero, foi lançado em 2009 o livro Leituras de resistência: corpo, violência, poder, dividido em dois extensos volumes, pela Editora Mulheres, de Florianópolis. O primeiro volume está dividido em quatro grandes temas e é composto de 22 artigos, 15 autoras e 7 autores, atingindo o número de 500 páginas. Com uma perspectiva nitidamente interdisciplinar, o que caracteriza não só os estudos de gênero como os estudos feministas, a obra prima por privilegiar os mais diferentes campos do conhecimento. Nesse sentido, são contempladas as perspectivas das mais variadas.

Em função da dimensão das obras, neste texto a reflexão recairá apenas sobre o segundo volume, composto de 20 artigos, 21 autoras e 1 autor, de distintas formações, distribuídos em mais de 400 páginas. A obra foi organizada por Carmen Susana Tornquist, Clair Castilhos Coelho, Mara Coelho de Souza Lago e Teresa Kleba Lisboa, professoras da UFSC e da UDESC, e é fruto das mesas-redondas que se realizaram durante a $8^{\circ}$ edição do Seminário Internacional Fazendo Gênero: Corpo, Violência e Poder, em 2008, na Universidade Federal de Santa Catarina, em Florianópolis. O evento, realizado desde 1992 em
Florianópolis, contou com mais de 2.700 inscritos, dos quais 1.600 eram apresentadoras $e$ apresentadores de trabalhos; foram 22 mesasredondas, 72 simpósios temáticos e mais de 300 apresentações de pôsteres.

Este segundo volume está dividido em quatro temáticas que dão nome às quatro grandes partes do livro: a primeira intitula-se "Memórias do feminismo" e traz os depoimentos de Danda Prado e Eva Alterman Blay; a primeira relatando o exílio durante a ditadura brasileira, uma memória individual, e a segunda dissertando sobre os limites dos direitos humanos quando o assunto são as mulheres, assunto discutido também pela historiadora Lynn Hunt, em obra recente, que aponta as mulheres como habitantes da linha-limite na extensa história da invenção dos direitos humanos. ${ }^{2}$

Os cinco artigos da segunda parte, "Violências silentes, corpos, subjetividades", apontam a construção e a subjetivação dos corpos maternos e dos corpos em sofrimento, como nos casos de "saúde mental". Cláudia Fonseca discute a noção de parentesco como constructo social, refletindo sobre o próprio conceito de abandono materno para dissertar sobre crianças dadas em adoção. Já Dagmar Estermann Meyer dedica-se em seu texto a refletir sobre o significado da maternidade no pensamento moderno ocidental, enquanto Ana Paula Vosne Martins discute a intervenção de técnicas médicas no "tornar-se mãe". Esses três primeiros artigos detêm como eixo temático a maternidade sendo apresentada como um problema. Adriana Valobra, ao tratar de violências silentes, enfoca múltiplas formas de violência, além das físicas propriamente ditas, destacando violências simbólicas também como formas de violência de gênero. Por último, Sônia Weidner Maluf, ao abordar o tratamento concedido a mulheres consideradas em depressão, acentua uma crescente psicologização do sujeito paralela à medicalização da subjetividade.

Na terceira parte, "Violências, trabalho, exclusões", podem ser identificados três subtemas distribuídos em nove artigos que são a questão do trabalho, a implementação de programas de combate à pobreza e a relação entre gênero e meio ambiente. No primeiro bloco, Hildete Pereira de Mello reflete sobre a invisibilidade do trabalho das mulheres, enquanto Cláudia Mazzei Nogueira aponta um estudo de 
caso sobre a situação de trabalho das operadoras de telemarketing. Já Maria Rosa Lombardi discute a crescente inserção das mulheres nas Forças Armadas e na Marinha do Brasil, apontando todas as suas contradições e obstáculos ainda a serem transpostos. Finalizando, Estela Grassi apresenta dados que pontuam as dificuldades das mulheres em se inserirem no mercado de trabalho. No bloco que reflete sobre programas sociais, Rosana Martinelli Freitas acentua a importância dos programas sociais que objetivam a distribuição de renda, mas ressalta suas limitações. Também Teresa Kleba Lisboa destaca o empoderamento como forma de alteração radical dos processos e das estruturas que localizam as mulheres como submissas, tendo os programas de assistência social participação nesse processo. Paola Cappellin acentua que igualdade, autonomia e reconhecimento só podem ser alcançados com a justa inserção das mulheres no mundo do trabalho. No último bloco deste terceiro capítulo, Rosa Ester Rossini e Sônia Alves Calió salientam a importância da inclusão das mulheres na luta pela preservação do ambiente, ao passo que Iraildes Caldas Torres, além de reforçar essa ideia, destaca a maior dedicação das mulheres à sustentabilidade.

Na quarta e última parte, "A lei no enfrentamento da violência doméstica", quatro artigos refletem sobre os problemas e os avanços da implementação da Lei Maria da Penha. Silvia de Aquinno relata as dificuldades de implementação da Lei Maria da Penha em Salvador. Já Maria Juracy Figueiras Tonelli e Simone Becker apontam um avanço teóricoaplicado, apresentando a Lei Maria da Penha como um marco ao pensar a categoria "gênero" como funcional. Nos dois últimos artigos, Benedito Medrado e Leila Linhares seguem um mesmo eixo, ao pensarem a importância do tratamento do agressor no processo de transformação e combate à violência contra a mulher.

Faço especial menção ao texto de Benedito Medrado, único homem dentre as autoras deste segundo volume, porque tive a oportunidade de assistir a sua fala e às manifestações furiosas e contrárias a sua postura de inclusão dos homens nas ações e nos debates sobre violência de gênero. Desse episódio e da leitura do texto de Medrado ressalto a relevância de se incluírem todos e todas na luta pela transformação.

É importante destacar que, mesmo passados dois anos de sua publicação, os artigos publicados representam discussões extrema- mente atuais. Destaco entre elas três questões: a) a inserção do evento na discussão sobre a Lei Maria da Penha, sancionada dois anos antes, em 2006; b) o debate sobre programas de complementação de renda; e c) as discussões sobre gênero e sustentabilidade.

Sobre a primeira, destaco o pioneirismo de se proporem ao debate a inclusão e o tratamento dos homens agentes de violência, no sentido de pensá-los como integrantes de um sistema de gênero.

Sobre a segunda questão, saliento a relevância dos programas sociais que visam ao "empoderamento" das mulheres, categoria pensada desde a década de 1970, como essencial na perspectiva feminista. ${ }^{3}$ No recente processo eleitoral presidencial de 2010, essa reflexão tornou-se ainda mais atual, visto que da nova presidenta, Dilma Roussef, espera-se a ampliação desses programas no sentido de transformação real. No entanto, as autoras que refletiram sobre esse tema acentuam que esse é apenas uma das vias de acesso ao poder para as mulheres.

Por último, aponto a discussão elaborada sobre gênero e meio ambiente, em que são louvadas as habilidades de mulheres no trato com a natureza. Nessa "onda da sustentabilidade" as mulheres são convocadas a restabelecerem seus laços com a mãe-terra. Certamente tal tema causa calafrios em muitas feministas que lutam há décadas para romper a ligação socialmente construída, mas dada como "natural", entre mulheres e natureza. Entretanto, é preciso pensarmos essa relação entre feminismo e movimento ambientalista ${ }^{4}$ de maneira mais complexa, talvez até como estratégica.

O segundo volume de Leituras de resistência: corpo, violência, poder, na sua amplitude temática e variada "raiz acadêmica", afirma-se como uma obra de referência para quem deseja aventurar-se em temas que embaraçam, provocam desconforto e exigem reação. Mais do que isso, ele é a prova do engajamento social da academia, que, mais do que refletir sobre determinados assuntos, interage com a sociedade no sentido de transformá-la, exemplo disso é citado em um dos artigos que apontam a inclusão da categoria "gênero" em uma lei que visa não só ao bem-estar das mulheres, mas da sociedade.

\section{Notas}

' HOUAISS, 2009.

2 Lynn HUNT, 2009

${ }^{3}$ Cecilia SARDENBERG, 2009.

${ }^{4}$ Marti KHEEL, 2008. 


\section{Referências bibliográficas}

HOUAISS. Dicionário eletrônico Houaiss da língua portuguesa. Rio de Janeiro: Objetiva, 2009.

HUNT, Lynn. A invenção dos direitos humanos: uma história. São Paulo: Companhia das Letras, 2009.

KHEEL, Marti. Nature Ethics: An Ecofeminist Pers- pective. Lanham, MD: Rowman \& Littlefield, 2008.

SARDENBERG, Cecilia. Liberal vs. Liberating Empowerment: Conceptualising Women's Empowerment from a Latin American Feminist Pespecive. Brighton, UK: Pathways of Women's Empowerment, 2009. v. 1.

Cíntia Lima Crescêncio Universidade Federal de Santa Catarina 